\title{
THE ROLE OF THE VIETNAMESE EDUCATION SYSTEM IN STARTING A BUSINESS
}

\author{
Khanh Hung DOAN \\ Doctoral School of Business Administration, Bucharest University of Economic \\ Studies, Bucharest, Romania \\ doankhanhhung.hat@gmail.com
}

\begin{abstract}
The education system plays an important role in human development. It is not only in terms of improving knowledge, solving social problems on many levels but also contributing to the development of the economic activities of a country. Moreover, entrepreneurship and entrepreneurial activities are also strongly influenced by the education system of the country. Today, entrepreneurial activities play an increasingly significant role in the development of the country. Therefore, it needs to be paid attention to and focused on the building of an educational environment suitable to the characteristics of entrepreneurship. From there, it is possible to create a dynamic environment, promote business development and start business activities of the country. This paper first provides a brief overview of the role of education in entrepreneurship. Next, the research method and research results are presented on assessing the current status of the role of the national education system in starting a business in Vietnam. The study is based on the analysis of data collected from the report provided by The Amway Global Entrepreneurship Report in 2018 (AGER) on national entrepreneurship in the specific case of Vietnam. Finally, the paper ends with some suggestions and conclusions of the study.
\end{abstract}

Keywords: education system; entrepreneurship; starting business; Vietnam.

JEL classification: I25; M13; M21

\section{Introduction}

In recent years, entrepreneurship and starting a business have always been interested and focused on development. This more and more enterprises are established and thrive. Furthermore, entrepreneurship and starting a business will contribute to the economic and social development of the country. Entrepreneurship is identified as the driving force for socio-economic development. Therefore, entrepreneurship plays an increasingly important role in the development policy of countries (Păunescu and Molnar, 2020). Besides, the goal of developing entrepreneurship on sustainability is a goal of countries around the world. So, it can be said that entrepreneurship and starting a business play a significant role in the national development policies, not only in developing countries but also in developed countries. Furthermore, entrepreneurship is considered a priority area in the national social and economic development policies (Fairlie, 2011).

In particular, the role of the education system in entrepreneurship and starting a business is increasingly appreciated and noticed. Education contributes to the promotion of individual entrepreneurship, supporting the necessary knowledge. It is 
not only at the start-up stage but also at the entire stage of business operation (Uzunidis et al., 2014; Păunescu et al., 2018). Therefore, countries need to have appropriate policies and regulations for education as well as the entrepreneurship and characteristics of that country. From there, it is possible to create the best educational environment for entrepreneurship, contributing to supporting, maintaining, and enhancing business start-up and business operations.

This article attempts to supplement a study of the current state of the educational system's influence on entrepreneurship and starting a business. The main objective of this paper is to assess the influence of the education system on entrepreneurship and starting a business, especially in a transitional economy and Vietnam's education system is still weak. In addition, differences in assessments of different groups based on the demographics of entrepreneurs are provided. Herein, a detailed view of the influence of the education system can be obtained. To accomplish the goals, the paper used an extensive review of the relevant literature and research to analyze the statistical data collected from The Amway Global Entrepreneurship Report (AGER) in 2018 on entrepreneurship, motivation, and desire to start a business in countries around the world. Finally, the conclusions and discussion of the research results are presented.

This paper has four main parts. The first part is an overview of the literature on the research issues. The second part introduces the research method used in this study. The third part presents the research results after data analysis and processing, as well as some initial evaluation of the research results. The final section concludes and discusses the results obtained from the study with some limitations and suggestions for future research directions.

\section{Literature review}

\subsection{The relationship between education and entrepreneurship}

Currently, there are many studies show that entrepreneurship plays an essential role in the economic and social development of each country (Hartono and Muzayanah, 2020; Prasetyo and Kistanti, 2020). Furthermore, entrepreneurship is considered as one of the main drivers for economic and social development, as generating many benefits both financially and socially around the world (OkahEfogo and Timba, 2015; Păunescu and Molnar, 2020). Therefore, promoting and enhancing entrepreneurship is a significant task of each country. Uzunidis et al. (2014) stated that the resources that entrepreneurs need to excel can be grouped into three main categories: (1) knowledge through education and professional experience; (2) financing through savings, loans, or grants; and (3) relationships through networks, family relationships, and personal relationships. There are many factors that affect entrepreneurship, such as policy, law, tax, technology, economic situation, income, age, social status, education, etc. Education is considered one of the important factors affecting business intention (Galloway and Brown, 2002; Fayolle et al., 2006; Zhang et al., 2013). Policymakers also believe that increasing the level of entrepreneurship can be achieved through education (European Commission, 2003) and primary education in entrepreneurship (Varadarajan Sowmya et al., 2010). Păunescu et al. (2018) also emphasized that education level is considered to be a strong determinant of entrepreneurial readiness and decision of entrepreneurs. Drucker (1985) further determined that entrepreneurship is a 
discipline. Therefore, it can be learned (Drucker, 1985). In addition, the establishment of startups is a core matter of entrepreneurship, and it requires basic knowledge, skills, and entrepreneurial behavior (Gartner, 1988). From there, some, if not all, aspects of entrepreneurship can be taught (Kuratko, 2005). Thus, education is the simple way to individual opportunity and social growth, and entrepreneurship education is especially significant to promote a bigger global economy (Varadarajan Sowmya et al., 2010).

According to Augustine et al. (2018), entrepreneurship education was first taught at Harvard University in 1947, and became popular in business schools in the 1970s, and began to receive the attention of scholars worldwide. Since then, many stories about the great benefits of entrepreneurship, such as economic, social, and educational, have been taught. It has led to an increase in entrepreneurship education programs in higher education institutions in the world (Charney and Libecap, 2000).

Do Paco et al. (2015) assessed that entrepreneurship education has a role to play in promoting entrepreneurial intentions and furthering enterprising citizens by improving management knowledge and developing psychological attributes and behaviors associated with entrepreneurship. Păunescu and Vidovic (2020) also argued that entrepreneurship courses contribute to awakening academic curiosity about the necessary topics and contents of social enterprises. Evaluating specifically, Piperopoulos and Dimov (2015) also observed that the nature of the entrepreneurship course - whether theoretically or practically oriented - creates a distinct framework for entrepreneurship, especially creating high efficiency for practical orientation courses of entrepreneurship courses for entrepreneurship. In addition, some studies suggest that higher education is an important factor in entrepreneurial decisions (Kerrin et al., 2017; Morales and Marquina, 2013; Mitchelmore and Rowley, 2013; Nehete et al., 2011).

Besides, many studies have shown that education has a positive effect on entrepreneurship/starting a business on many factors:

- Firstly, entrepreneurship education helps increase the ability to learn and identify new business opportunities (Hussain and Norashidah, 2015). Such knowledge leads to increased quantity and innovation of opportunities associated with technology (Shepherd and DeTienne, 2005). Learning entrepreneurial skills and competencies will lead to individuals perceiving new possible ventures, thereby affecting entrepreneurship (Krueger et al., 2000; Zhao et al., 2005). Besides, social entrepreneurship education helps people acquire the necessary skills and knowledge (Păunescu and Vidovic, 2020).

- Secondly, research shows a positive association between social desire and entrepreneurial intention (Tkachev and Kolvereid, 1999; Bae et al., 2014). Research by Moore (2002) concludes there is a positive relationship between education and the probability of starting a business. Besides, Fellnhofer's study (2018) also showed that individuals' perceptions of entrepreneurial ability and business intention were significantly different before and after exposure to business stories. Thus, entrepreneurial aspirations can be influenced through education (Krueger and Brazeal, 1994), and support for entrepreneurship from relevant sources (possibly educational programs) can increase the likelihood of entrepreneurship (Riquelme and AI Lanqawi, 2016).

- Thirdly, entrepreneurship courses help to gain knowledge about starting a new business in a better and faster way that leads to more value from similar 
opportunities (Zhao et al., 2005; Davidsson and Honig, 2003). Furthermore, education includes not only the development of economic skills but also the focus on business realities (Păunescu et al., 2018) and improving one's effectiveness (Diaz-Garcia et al., 2015). Researchers advocate entrepreneurship education as an alternative to traditional learning about the basics of how to run a business. Topics of recognition and exploitation of opportunities, creativity, and innovation to promote social development (Sánchez, 2011) were also appreciated.

Research by Kerrin et al. (2017) confirmed that, even in emerging economies with poor education systems, courses in entrepreneurship increase the desire for entrepreneurship and entrepreneurship. Following the same idea, research conducted by Diaz-Garcia (2015) in the academic field demonstrates a higher interest in the desire to start a business in students after completing a course in entrepreneurship. Furthermore, Pajarinen et al. (2006) argued that the evidence suggests that educated entrepreneurs are more important in developing regional economies than less educated entrepreneurs. Accordingly, more educated entrepreneurs are more likely to innovate, use modern business models, and base their businesses on new technologies (Pajarinen et al., 2006).

However, some studies suggest that the influence of education on entrepreneurial intention is limited (Byabashaija and Katono, 2011) or has no effect on entrepreneurship (Praaf and Ophem, 1995). Specifically, a study in Serbia on the educational level of entrepreneurs showed that only $10.8 \%$ of the total number of entrepreneurs surveyed had a college or university degree, and the rest have less than a university degree or have not completed primary school (Stefanović and Stošić, 2012). This result is explained by unsatisfactory work conditions, so people choose to start a business or because of unemployment (Stefanović and Stošić, 2012). Deli (2011) argued that people with less ability to become entrepreneurs are not necessary, while those with higher skills choose to start a business because of opportunity. Research by Păunescu et al. (2018) pointed out that in Romania, it is not that the higher the educational attainment, the stronger the desire to start a business. Therefore, we need an overview of the role of education in entrepreneurship.

\subsection{Education system for entrepreneurship in Vietnam Invest in the education system in Vietnam}

Table 1: State budget spent on education system in Vietnam

\begin{tabular}{|c|c|c|c|c|}
\hline Criteria & $\mathbf{2 0 1 5}$ & $\mathbf{2 0 1 6}$ & $\mathbf{2 0 1 7}$ & $\mathbf{2 0 1 8}$ \\
\hline Budget for Education system (Billion USD) & 8.003 & 8.504 & 9.355 & 9.995 \\
\hline Budget for Higher system (Billion USD) & 0.664 & 0.850 & 0.907 & 0.996 \\
\hline $\begin{array}{c}\text { GDP of Vietnam (Billion USD) } \\
\text { Ratio of state budget expenditure for } \\
\text { education and training to GDP (\%) }\end{array}$ & 193.2 & 205.3 & 223.9 & 240.5 \\
\hline $\begin{array}{c}\text { Ratio of state budget expenditure for higher } \\
\text { education to GDP (\%) }\end{array}$ & 0.34 & 0.14 & 4.56 & 4.14 \\
\hline $\begin{array}{c}\text { Ratio of state budget for Higher system for } \\
\text { Education system (\%) }\end{array}$ & 8.3 & 10 & 9.42 & 0.41 \\
\hline
\end{tabular}

Source: Nguyen and Cicea (2019) 
Investment in the education system is an essential issue of any country. Table 1 shows the extent of national budget investment in the education system in Vietnam between 2015 and 2018. Through table 1, we can see that the percentage of Vietnam's budget investment in education is still low. Although the budget value increases, the level of investment in education accounts for a small proportion and has little change over the years. The investment rate for Vietnam's education system accounts for about $4.14 \%$ of the total GDP value (in 2017, there was an increase of $4.56 \%$ but decreased to $4.14 \%$ in 2018). Herein, the investment rate for higher education only accounts for about $10 \%$ of the total investment rate for the education system in Vietnam. It reflects that the Vietnamese government has not focused on investing in higher education and higher education but only investing in other levels of education such as secondary education and primary education. This result has a significant impact on entrepreneurship education activities in Vietnam.

\section{Some support programs for entrepreneurship education in Vietnam}

Identifying entrepreneurship and starting a business as key to economic development in Vietnam, the Vietnamese government also considers and focuses on promoting the development of entrepreneurship through support programs, education, and training programs for students and other entrepreneurs. In recent years, Vietnam has had some policies to promote the entrepreneurship of the country, including enacting through the "Supporting the national innovative start-up ecosystem to 2025" - Project 884; "Supporting start-up in students until 2025" project 1665, "Propaganda, education, advocacy and support for women to participate in solving some social issues related to women period 2017 - 2025" project 939 (Vietnamese Government, 2016a; 2016b; Vietnam Women's Union, 2017). These policies have had strong effects on entrepreneurship as well as starting a business in Vietnam. Furthermore, if there are more and more training programs, entrepreneurial activities are carried out on many levels and in many different localities. These programs not only contribute to the promotion of entrepreneurship but also enhancement of knowledge and information support of entrepreneurs. Therefore, this is a significant driving force contributing to the promotion and support of entrepreneurship and improving the sustainable development of businesses in Vietnam.

\section{Evaluation of entrepreneurship education in Vietnam}

To assess the overall performance of Vietnamese startup education, the author used two indicators, Basic School Entrepreneurial Education And Training and Post School Entrepreneurial Education And Training, from the GEM report. These are two indicators that give an overview of entrepreneurship education in Vietnam. The results in Table 2 show that the evaluation level of entrepreneurship education in Vietnam is low (Basic School Entrepreneurial Education And Training is under 2, and Post School Entrepreneurial Education And Training is under 3 out of 5 scales). Besides, this rating tended to decrease from 2013 to 2015 and recovered in 2017, but the overall trend is still down. It raises the issue that entrepreneurship education in Vietnam has not been focused on and is concerned by stakeholders. In addition, entrepreneurs have not yet appreciated the activities of the entrepreneurship education program at all educational levels in Vietnam.

In recent years, although the Vietnamese government has paid particular attention to the development of entrepreneurship education, the effectiveness of those 
educational programs is still limited. Therefore, an overview of the assessment of Vietnam's education policies on entrepreneurship and entrepreneurship is needed. From there, it provides some solutions and recommendations to the Vietnamese government that can make changes, adjust policies in a way that is suitable for different characteristics of different audiences and ensure the development, promote entrepreneurship, starts a business in Vietnam in the best way.

Table 2: Entrepreneurial Education in Vietnam over years

\begin{tabular}{|c|c|c|c|c|}
\hline Criteria & $\mathbf{2 0 1 3}$ & $\mathbf{2 0 1 4}$ & $\mathbf{2 0 1 5}$ & $\mathbf{2 0 1 7}$ \\
\hline Basic School Entrepreneurial Education And Training & 1.97 & 1.83 & 1.57 & 1.83 \\
\hline Post School Entrepreneurial Education And Training & 2.64 & 2.64 & 2.53 & 2.61 \\
\hline
\end{tabular}

Source: Global Entrepreneurship Monitor (2021)

\section{Research Methodology}

The purpose of this paper is to assess the actual impact of the education system on starting a business in Vietnam. From there, there is an overview of the role of education in entrepreneurship activities in Vietnam today. To achieve the above purpose, the paper has analyzed through statistic data collected from the survey of The Amway Global Entrepreneurship Report (AGER) in 2018. Accordingly, AGER is a global survey to survey the public about the state of entrepreneurship as well as the motivation and desire to start a business of individuals in countries around the world. The Amway Global Entrepreneurship Report (AGER) 2018 is based on a survey of 48,998 entrepreneurs in 44 countries in the world, including different continents. The data of the research were collected at the 2018 AGER survey. The question in the AGER Report relevant to the education system used for analysis is:

- With which of the following statements about your country do you agree?

- For starting and running a business, the education system in my country teaches people the skills they need.

To conduct an assessment of the influence of national policies on entrepreneurship, the analytical method used in this paper is the statistical analysis method. The data were entered, scanned, and analyzed through Microsoft Excel software to identify patterns and extract relevant factors for the study. The results are presented related to the data statistically.

\section{Results}

Out of the 48,998 observations obtained from the AGER report, the total number of observed samples in the AGER research data for the year for Vietnam includes 1040 observed samples. This paper will use all of these 1040 observed samples to conduct analysis in our research.

Statistical analysis results show that there is a high rate of agreement (more than $50 \%$ of individuals choose the given factors), and there is a significant difference in those ratings among the national factors affecting and running a business. However, the agreement rate on The influence of the education system on starting a business and running a business is the lowest (61.9\%) compared to other criteria such as The national tax policies which have the highest approval rate with $77.5 \%$ 
of respondents, followed by Beneficial economic situation (70.5\%), Technology availability $(66.5 \%)$, The national rules and regulations $(63.8 \%)$, and finally The national education system (61.9\%). This result proves that, although the influence of the education system is highly appreciated, it is still not considered in the factors affecting the operation and management of enterprises.

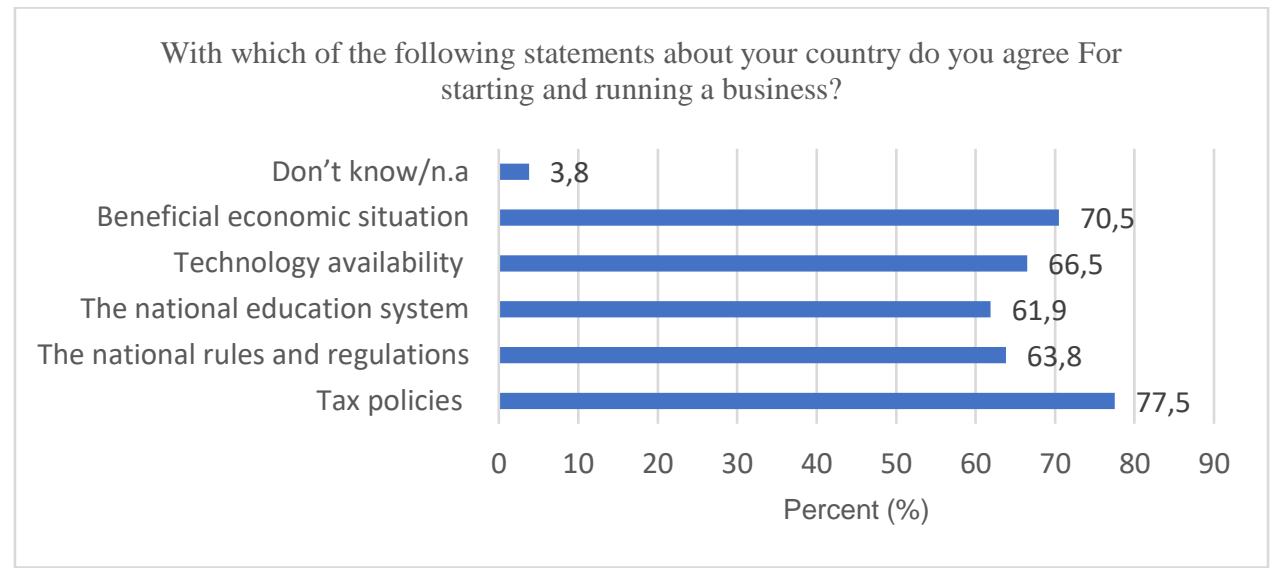

Figure 1: National factors affecting starting a business

Source: Compiled by the author using data from AGER.

In addition, comparing the difference between the assessment level in Vietnam compared with the average level in Asia and the average level in the world, the Vietnamese education system is rated higher than the average level of Asia (53\%) and the whole world (40\%). This result shows that the role of the education system still has a strong influence on entrepreneurship and starting a business in Vietnam.

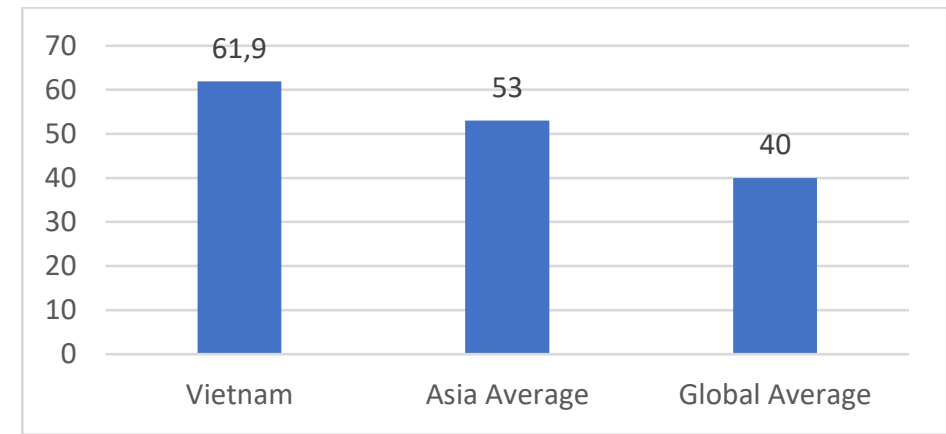

Figure 2: Comparison of consent rates for Vietnamese education with Asia averages and Global averages

Source: Compiled by the author using data from AGER.

To further clarify the difference in assessment for the education system in Vietnam, the paper continues to go into a detailed assessment of different target groups, characteristics, and criteria.

Statistical analysis shows a difference in the degree of agreement about the influence of the national education system in Vietnam on entrepreneurship. In 
detail, the consent rate of females $(67.3 \%)$ is higher than that of males $(55.9 \%)$. Regarding age, individuals with older age rated higher than individuals with younger. The consent rate of individuals aged from 36 to 69 was $67.7 \%$, and the individuals aged from 15 to 35 years old was $57.2 \%$. This result shows that there is a big difference in the assessment of age as well as gender.

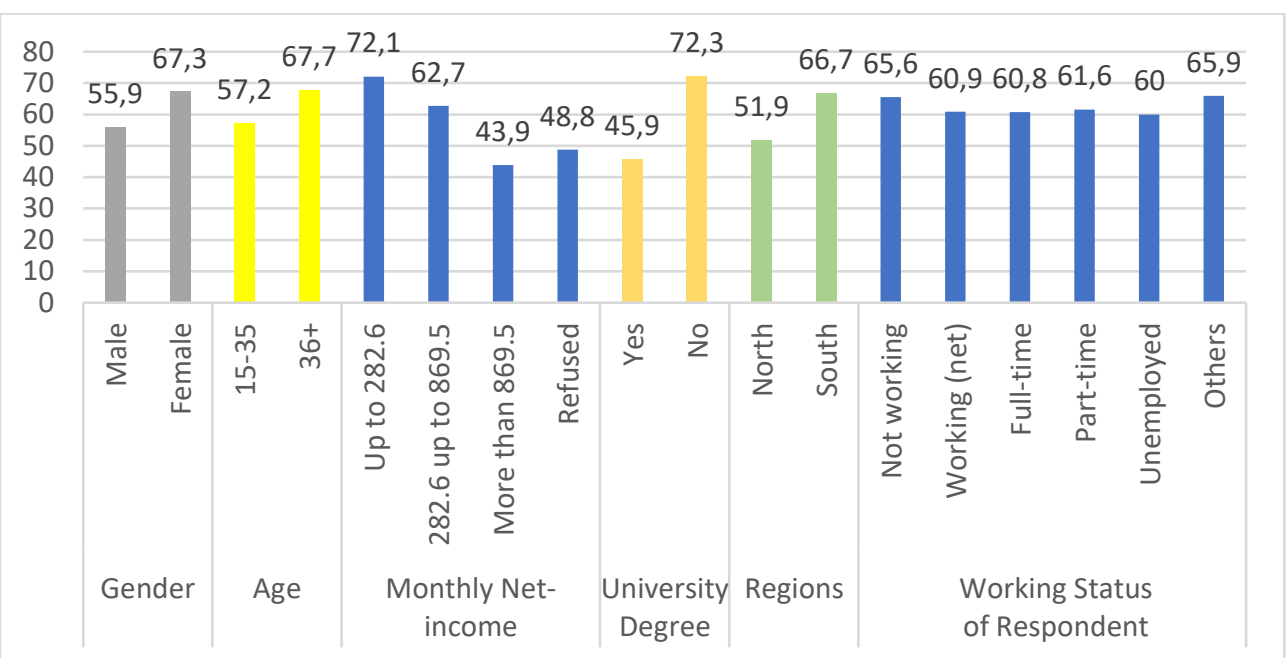

Figure 3: Differences in individual groups' evaluations of the education system Source: Compiled by the author using data from AGER.

Regarding the structure of respondents by Net-income, there is a tendency to gradually decrease the rate of agreement when the income of individuals increases. The highest rating rate was $72.1 \%$ for the lowest income group (\$280/month) and fell to $43.9 \%$ for the highest income group (more than $\$ 1300 /$ month). This result suggests quite interestingly that the higher the income, the less important the influence of education in providing the skills and knowledge needed to start a business.

Regarding university degrees, among the agreement respondents, $45.9 \%$ have a university degree, and $72.3 \%$ do not have a university degree. It is quite true with the proportion of people with university degrees in Vietnam today when the proportion of people with university degrees tends to increase over the years but still does not account for a high percentage of the population. Besides, in Vietnam, many people who do not have a university degree are hard to find a job, so they will start a business more than those who have a university degree. So, people without university degrees have some difficulties when they lack some knowledge to apply in their business activities, and they think that the education system will support this. However, studying in Vietnam is still academic, with much theory, little practice/practice, so the percentage of university degree holders agreeing is not high (only $45.9 \%$ ).

In addition, the agreement rate of individuals living in the South $(66.7 \%)$ is higher than that of respondents living in the North of Vietnam (51.9\%). This result is understandable because the economy in Vietnam is more developed and has a much more dynamic business environment than in the North. Therefore, many 
highly qualified people looking for job and business opportunities are higher in the South than in the North.

Regarding the characteristics of employment status, the group of Not working individuals had the highest rating $(65.6 \%)$ compared to the remaining groups with a fairly balanced assessment (about 61\%).

Through the analysis, the results show that there is the influence of the national education system on entrepreneurship in Vietnam is uneven. In this respect, the majority of surveyed individuals agree that the national education system has an influence on entrepreneurship and starting a business in Vietnam. Furthermore, the education factor is not the most important factor when starting a business. It is also influenced by internal factors of individuals as well as external social and environmental factors more than educational factors. In addition, characteristics such as age, monthly income, university degree, employment status, and place of residence are useful in determining differences in the influence of national education on entrepreneurship and starting a business.

\section{Discussion and Conclusion}

Entrepreneurs are always expected to improve their qualifications, knowledge, and skills to meet their learning needs, improve their professional skills and adapt to the changing business and social environment. From there, entrepreneurs can ensure the development and enhancement of enterprises' operations. Therefore, countries and governments need to have solutions and policies for the education and training system in a reasonable way to contribute to ensuring the development of entrepreneurship of individuals in the best way.

However, the results in this paper in Vietnam show that although the education system has an impact on entrepreneurship, it is the most underrated criterion compared to others when starting a business. Another aspect that needs to be mentioned is that education needs to focus on differences in individual characteristics because there are differences in assessment between different groups. From there, the government can come up with appropriate solutions to improve the effectiveness of the education system in promoting and supporting entrepreneurial activities and starting businesses.

In general, the national education system has many benefits, meanings. It contributes different significant roles in the development of the country and each individual. Thus, it can be seen and understood that an indispensable role of the education system is to help individuals have the foundation and initial knowledge and foster and improve each person's capacity. From there, its contribution is to help entrepreneurs start their business smoothly, limiting certain mistakes in their business process. Therefore, identifying and analyzing the influence, role, and relationship of education on entrepreneurship is an interesting issue. This issue needs to be studied the next time.

In addition, the study has some limitations. First, because it is based on the available data of AGER, there is little analysis of other aspects of the influence of the education system on entrepreneurship and starting a business. Besides, it is also hard to go into the specific analysis of the characteristics of the education system. Therefore, the study has many limitations and cannot generalize all the 
characteristics of the research subjects. These are good research directions that can be done in the future.

\section{References}

1. Augustine, I.J., Emmanuel, E.B., Sunday, A., Inalegwa, I. and Ogilegwa, A.D., (2018). Entrepreneurship Education and Economic Growth of Benue State (2007 2016). Journal of Business and Management, 20 (5), pp. 62-75.

2. Bae, T.J., Qian, S., Miao, C. and Fiet, J.O. (2014). The relationship between entrepreneurship education and entrepreneurial intentions: A meta-analytic review. Entrepreneurship theory and practice, 38(2), pp. 217-254.

3. Byabashaija, W. and Katono, I. (2011). The impact of college entrepreneurial education on entrepreneurial attitudes and intention to start a business in Uganda. Journal of Developmental Entrepreneurship, 16(01), pp. 127-144.

4. Charney, A. and Libecap, G.D., (2000). The impact of entrepreneurship education: an evaluation of the Berger Entrepreneurship Program at the University of Arizona, pp. 1985-1999.

5. Davidsson, P. and Honig, B. (2003). The role of social and human capital among nascent entrepreneurs. Journal of business venturing, 18(3), pp. 301-331.

6. Deli, F. (2011). Opportunity and necessity entrepreneurship: Local unemployment and the small firm effect. Journal of Management Policy and Practice, 12(4), pp. 38-57.

7. Díaz-García, C., González-Moreno, Á., and Sáez-Martínez, F.J. (2015). Ecoinnovation: insights from a literature review. Innovation, 17(1), pp. 6-23.

8. Díaz-García, C., Sáez-Martínez, F. and Jiménez-Moreno, J. (2015). Assessing the impact of the "Entrepreneurs" education programme on participants' entrepreneurial intentions. International Journal of Educational Technology in Higher Education, 12(3), pp. 17-31.

9. Do Paço, A., Ferreira, J.M., Raposo, M., Rodrigues, R.G. and Dinis, A. (2015). Entrepreneurial intentions: is education enough?. International Entrepreneurship and Management Journal, 11(1), pp. 57-75.

10. Drucker, P.F. (1985). Entrepreneurial strategies. California Management Review, 27(2).

11. European Commission, (2003). Green Paper: Entrepreneurship in Europe, Luxembourg.

12. Fairlie, R.W. (2011). Entrepreneurship, economic conditions, and the great recession. IZA Discussion Paper No. 5725. Bonn, Germany: IZA.

13. Fayolle, A., Gailly, B. and Lassas-Clerc, N. (2006). Assessing the impact of entrepreneurship education programmes: a new methodology. Journal of European Industrial Training, 30(9), pp. 701-720.

14. Fellnhofer, K. (2018). Narratives boost entrepreneurial attitudes: Making an entrepreneurial career attractive?. European Journal of Education, 53(2), pp. 218237.

15. Galloway, L. and Brown, W. (2002). Entrepreneurship education at university: a driver in the creation of high growth firms?. Education+ Training, 44(8/9), pp. 398405.

16. Gartner, W.B. (1988). "Who is an entrepreneur?" is the wrong question. American Journal Of Small Business, 12(4), pp. 11-32. 
17. Hartono, D. and Muzayanah, I. F. U. (2020). The roles of entrepreneurship on regional economic growth in Indonesia. Journal of the Knowledge Economy, 11(1), pp. 28-41.

18. Hussain, A. and Norashidah, D. (2015). Impact of entrepreneurial education on entrepreneurial intentions of Pakistani Students. Journal of Entrepreneurship and Business Innovation, 2(1), pp. 43-53.

19. Kerrin, M., Mamabolo, M.A. and Kele, T. (2017). Entrepreneurship management skills requirements in an emerging economy: A South African outlook. The Southern African Journal of Entrepreneurship and Small Business Management, 9(1), pp. 1-10.

20. Krueger Jr, N.F. and Brazeal, D.V. (1994). Entrepreneurial potential and potential entrepreneurs. Entrepreneurship theory and practice, 18(3), pp. 91-104.

21. Krueger, N.F., Reilly, M.D. and Carsrud, A. L. (2000). Entrepreneurial intentions: A competing models approach. Journal of Business Venturing,15(5/6), pp. 411-432.

22. Kuratko, D.F. (2005). The emergence of entrepreneurship education: Development, trends, and challenges. Entrepreneurship theory and practice, 29(5), pp. 577-597.

23. Mitchelmore, S. and Rowley, J. (2013). Entrepreneurial competencies of women entrepreneurs pursuing business growth. Journal of small business and enterprise development, 20(1), pp. 125-142.

24. Moore, C.S. and Mueller, R.E. (2002). The transition from paid to selfemployment in Canada: the importance of push factors. Applied Economics, 34(6), pp. 791-801.

25. Morales, C.E. and Feldman, P.M. (2013). Entrepreneurial skills, significant differences between Serbian and German entrepreneurs. Journal of CENTRUM Cathedra: The Business and Economics Research Journal, 6(1), pp. 129-141.

26. Nehete, R.S., Narkhede, B.E. and Mahajan, S.K. (2011). Investigation of entrepreneurial skills for better performance of manufacturing SMEs. International Journal of Engineering Science and Technology, 3(7), pp. 5515-5525.

27. Nguyen, T.H.T. and Cicea, C. (2019). Budget allocation policy for public higher education in Vietnam: a short radiography and future trends. In Proceedings of the International Management Conference (Vol. 13, No. 1, pp. 448-456). Faculty of Management, Academy of Economic Studies, Bucharest, Romania.

28. Okah-Efogo, F. and Timba, G.T. (2015). Female entrepreneurship and growth in Cameroon. African Journal of Economic and Management Studies, 6(1), pp. 107-119.

29. Pajarinen, M., Rouvinen, P. and Yla-Anttila, P. (2006), Ministry of Employment and the Economy, Helsinki.

30. Păunescu, C. and Molnar, E. (2020). Country's entrepreneurial environment predictors for starting a new venture-evidence for Romania. Sustainability, 12(18), 7794.

31. Păunescu, C. and Vidovic, D (2020), Social Entrepreneurship Education in Academia: A MOOC Scheme Analysis, Proceedings of the 3rd International Conference on Economics and Social Sciences, ISSN 2704- 6524, pp. 491-501.

32. Păunescu, C., Popescu, M.C. and Duennweber, M. (2018). Factors determining desirability of entrepreneurship in Romania. Sustainability, 10(11), 3893. 
33. Piperopoulos, P. and Dimov, D. (2015). Burst bubbles or build steam? Entrepreneurship education, entrepreneurial self-efficacy, and entrepreneurial intentions. Journal of small business management, 53(4), pp. 970-985.

34. Praag, C.M.V. and Ophem, H.V. (1995). Determinants of willingness and opportunity to start as an entrepreneur. Kyklos, 48(4), pp. 513-540.

35. Prasetyo, P.E. and Kistanti, N.R. (2020). Human capital, institutional economics and entrepreneurship as a driver for quality \& sustainable economic growth. Entrepreneurship and Sustainability Issues, 7(4), pp. 2575-2589.

36. Riquelme, H.E. and Al-Lanqawi, A.M. (2016). The desire that propels entrepreneurial intentions. Journal of Entrepreneurship, Management and Innovation, 12(2), pp. 123-150.

37. Sánchez, J.C. (2011). University training for entrepreneurial competencies: Its impact on intention of venture creation. International Entrepreneurship and Management Journal, Vol. 7 No. 2, pp. 239-254.

38. Shepherd, D.A. and DeTienne, D.R. (2005). Prior knowledge, potential financial reward, and opportunity identification. Entrepreneurship theory and practice, 29(1), pp. 91-112.

39. Stefanović, S. and Stošić, D. (2012). Age and education as determinants of entrepreneurship. Facta Universitatis-series Economics and Organization, 9(3), pp. 327-339.

40. Tkachev, A. and Kolvereid, L. (1999). Self-employment intentions among Russian students. Entrepreneurship \& Regional Development, 11(3), pp. 269-280. 41. Uzunidis, D., Boutillier, S. and Laperche, B. (2014). The entrepreneur's 'resource potential'and the organic square of entrepreneurship: definition and application to the French case. Journal of Innovation and Entrepreneurship, 3(1), 1. 42. Varadarajan Sowmya, D., Majumdar, S. and Gallant, M. (2010). Relevance of education for potential entrepreneurs: an international investigation. Journal of small business and enterprise development, 17(4), pp. 626-640.

43. Vietnam Women's Union (2017). Propaganda, education, advocacy and support for women to participate in solving a number of social issues related to women period 2017 - 2025. Project No.939. [07 Nov 2021] (In Vietnamese).

44. Vietnamese Government (2016a). The project "Supporting the national innovation start-up ecosystem to 2025". Project No.884. [Online], Available: http://vanban.chinhphu.vn/portal/page/portal/chinhphu/hethongvanban?class_id=2 \&_page $=1 \&$ mode=detail\&document_id=184702, [07 Nov 2021] (In Vietnamese). 45. Vietnamese Government (2016) $)$. The project "Supporting start-up in students until 2025". Project No.1665. [Online], Available: https://thuvienphapluat.vn/vanban/Giao-duc/Quyet-dinh-1665-QD-TTg-2017-de-an-Ho-tro-hoc-sinh-sinh-vienkhoi-nghiep-den-nam-2025-365846.aspx. [07 Nov 2021]. (In Vietnamese).

46. Zhang, Y., Duysters, G. and Cloodt, M. (2013). The role of entrepreneurship education as a predictor of university students' entrepreneurial intention. International Entrepreneurship and Management Journal, 10, pp. 623-641.

47. Zhao, H., Seibert, S.E. and Hills, G.E. (2005). The mediating role of selfefficacy in the development of entrepreneurial intentions. Journal of Applied Psychology, 90(6), 1265. 